Kansas State University Libraries

New Prairie Press

Academic Chairpersons Conference

37th Academic Chairpersons Conference,

Proceedings

Savannah, GA

\title{
Executive Presence for the Academic Chair
}

Trey Guinn

University of the Incarnate Word, tguinn@uiwtx.edu

Follow this and additional works at: https://newprairiepress.org/accp

Part of the Educational Leadership Commons, Higher Education Administration Commons, Interpersonal and Small Group Communication Commons, and the Organizational Communication

Commons

(c) (1) (2)

This work is licensed under a Creative Commons Attribution-Share Alike 4.0 License.

\section{Recommended Citation}

Guinn, Trey (2020). "Executive Presence for the Academic Chair," Academic Chairpersons Conference Proceedings. https://newprairiepress.org/accp/2020/leadership/14

This Event is brought to you for free and open access by the Conferences at New Prairie Press. It has been accepted for inclusion in Academic Chairpersons Conference Proceedings by an authorized administrator of New Prairie Press. For more information, please contact cads@k-state.edu. 


\section{Executive Presence for the Academic Chair}

\section{Trey Guinn}

\section{*This is a revised version of an interactive workshop delivered in February 2019 at K-State in Houston and also built on a recent article published in The Department Chair}

In this session, we start with the premise that executive presence is a communicative phenomenon. More than our technical skills, our communication skills shape our executive presence and effectiveness. To shape opinion, inspire change and achieve results, we must create persuasive messages and deliver them with impact. This will be an interactive session that emphasizes how communication skills, presentation tips and interpersonal competencies enhance our executive presence and shape our effectiveness around the office and in the home. Participants can expect to leave with a fresh perspective on how to be a more clear, concise, compelling and confident communicator ready for and more capable of achieving effective executive presence. Bring a positive attitude and be ready to learn while having a little fun.

Strengthening communication skills enhances effectiveness as chairperson and beyond. To inspire change and achieve results, chairpersons must create and deliver persuasive messages with impact. Following an interactive workshop loaded with laughter, group activity, role-play, and various simulations, participants will leave with fresh perspective on how to be a more clear, concise, compelling, and confident communicator.

Communication is central to people's lives, and our success and failures, both personal and professional, are linked to our skills as communicators. Yet my research and lived experiences have taught me that academics are notorious for taking communication for granted. This is due to a variety of reasons, but the truth is that our ability to communicate effectively matters. Given the challenges and complexities of being chairpersons, improving communication skills and interpersonal savvy matters even more.

For this interactive workshop, we will start by laying a framework that communication as a chairperson is consequential. We then engage one another in a series of activities designed to illustrate how communication skills, presentation tips, and interpersonal competencies enhance our executive presence and effectiveness in the classroom, conference room, office space, online, and even over coffee with a colleague. Participants can expect to leave with a fresh perspective on how to be a more clear, concise, compelling, and confident communicator. Activities will be engaging and offer meaningful takeaway. As well, facilitator will provide handouts that can be used and referenced well-beyond the workshop. But anyone allergic to laughing and having fun while learning should most definitely avoid this workshop. 